\title{
OBITUARIES
}

\section{Mr. J. T. Davey and Mr. H. J. Morris}

IN the air disaster at Bordeaux on September 24, the International African Migratory Locust Organization, which exists to prevent the escape of swarms of the Migratory locust from the recognized outbreak area in the flood plains of the Niger, south-west of Timbuktu, suffered a very severe blow. The fiftythree people killed included no less than eight associated with that Organization: Mr. J. T. Davey, aged thirty-six, director of research; Mr. H. J. Morris, aged thirty-six, an experienced seientist newly appointed as an assistant to Mr. Davey, and his wife ; Madame Duhart, wife of Monsieur A. J. Duhart, director of survey and control, and one of their children; and Monsieur J. J. Rey, one of the locust control officers, and his wife and child.

James Thomas Davey graduated from the University of Bristol and then took a diploma in agriculture at Cambridge and spent a year at the Imperial College of Tropical Agriculture in Trinidad. $\mathrm{He}$ first went to Africa in 1947 as an entomologist in the Department of Agriculture in Nigeria, where he investigated the habits and ecology of certain species of biting flies (tabanids and tsetse flies). At the same time, he became interested in locusts, and in $1948 \mathrm{he}$ embarked on a detailed ecological study of the African Migratory locust, partly in association with $\mathrm{H}$. B. Johnston. Particular attention was paid in this study to the neighbourhood of Lake Chad, which was under suspicion as a possible outbreak area, and the important conclusion was reached that while the Migratory locust does oceasionally swarm there, the Chad area is not comparable as a source of swarms with the recognized outbreak area in what was then the French Sudan.

With this valuable experience behind him, he accepted in 1951 an invitation from the International African Migratory Locust Organization to visit the outbreak area on the Niger in order to extend investigations already begun by others of the ecology and seasonal movements of the locust there. His secondment to that Organization by the Government of Nigeria for this purpose was extended in 1952 for two years. An outcome of this mission was a decision by the Council of the Organization to establish a permanent Research Service. Davey became director of it, and he continued in that eapacity until the time of his death. Through his own ability and personal qualities, including a very thorough practical knowledge of French acquired mainly by usage, the Research Service and its scientific work became integrated into the Organization in a highly successful manner, which could not have been achieved without the respect, affection and support which he won from all his colleagues.

His scientific work consisted mainly of studies of the seasonal movements of the locust population in and around the Niger plains in relation to the seasonal rainfall, river-level and flooding of the plains by overflow from the river. By means of an impressive programme of field-work which involved the marking of more than a million locusts individually with paints, during a period of four years, and releasing them in particular localities in and outside the plains in the hope of recapturing some of them elsewhere, he succeeded in demonstrating a regular seasonal shift of population (already suspected by G. Remaudière, who conducted an ecological study of the locust in the flood plains during $1949-50$ ) between the plains and the surrounding arid country. His work further indicated that certain parts of the plains are far more important than others as breeding grounds of the locust. A much better understanding of the outbreak area as such has resulted from these investigations, and this has led to im. portant improvements and economies in the supervision and preventive control of the locust.

Davey travelled widely in Africa in the course of his duties. In 1953 he visited the outbreak areas of the Red locust in Northern Rhodesia and Tanganyika and toured parts of the vast area of eastern Africa over which the Desert Locust Survey, which has its headquarters in Nairobi, operates. Recently, he went to the Sudan Republic to see and discuss with the authorities there the circumstances in which a local increase in the population of the Migratory locust had occurred. His interests were wide and he was a good companion on journeys in remote places. His zest for life and his vigour and resourcefulness enabled him to take in his stride the many difficulties, some of them severe, which arise in 'bush travel' in Africa. The wild life of Africa appealed to him greatly. He knew the mammals of his areas well and was a keen shot, but he never shot animals solely for the sake of shooting. In connexion with his work, he made extensive collections of grasshoppers and plants, and these have added considerably to knowledge of the acridid fauna and the flora of the Niger flood plains and the surrounding country.

Fortunately, he made a point of writing accounts of his work at frequent intervals, and very little of the work that he had completed will be lost. His most important publications are two long papers on the ecology of the Migratory locust in what he called the Central Niger Delta ; these form part of a planned series of three, and it is understood that the third part was virtually complete in typescript when he died. It is fitting that this valuable series of papers is being published in Locusta, the journal of the international organization which he served so well.

The death of 'Jimmy' Davey, while still young, removes a man who was confidently expected to play an important part in the field of locust research and control in the future. His wife survives him, with three young children.

Hilary Jolliffe Morris graduated from St. John's College, Oxford, in 1948. A few years later he joined the Research Division of the Ministry of Agriculture of the Sudan, where he undertook pioneer studies of techniques of control of the Desert locust. This work, which covered a period of five years, contributed significantly to the development of aircraft-spraying and of low-volume ground-spraying against locusts, and in the course of it he became familiar with methods for the field-assessment of spray deposits and of the results of spraying operations.

In 1957 he joined the Colonial Pesticides Research Unit at Porton Down, near Salisbury, England, where 


\section{No. 4693 October 10, 1959}

he was occupied for two years in laboratory work on the toxicity of new insecticides to mosquitoes. He was essentially a field-man, however, with a strong liking for Africa and a desire to resume locust research, and when a suitable opening occurred in the Research Service of the International African Migratory Locust Organization he applied for the post and was selected.

This new appointment was for an investigation of the applicability of modern methods of locust control, particularly spraying from aireraft, in the conditions of the outbreak area of the Migratory locust on the Niger. Morris was very well fitted by his accumulated experience and personal qualities for this important task, and he set out with high hopes and keen interest on the journey which was to have taken him to the sort of work that he liked best and considered worth while because of its benefit to Africa.

Mr. and Mrs. Morris had been married only six months when they died. $\quad$ T. H. C. TAYLOR

\section{NEWS and VIEWS}

Scientific Adviser to the Ministry of Defence : Sir Frederick Brundrett, K.C.B., K.B.E.

Ir has been announced that Sir Frederick Brundrett will be retiring at the end of the year from his post of scientific adviser to the Ministry of Defence, and chairman of the Defence Research Policy Committee, shortly after his sixty-fifth birthday. Sir Frederick has had a life-time's association with the scientific aspects of defence, initially within the Admiralty, and for the past ten years of his career dealing with defence science in all its aspects. A member of the R.N.V.R. in the First World War, he joined the scientific staff of the Admiralty in 1919 and remained at H.M. Signal School, Portsmouth, until 1937, when he moved to headquarters. His remarkable qualities as a scientific administrator and his perception of scientific ability were given full scope during the Second World War, when he made a major contribution to the selection and allotment of scientists to the several departments needing them. Since the War his talents for organization have been given full rein at the Admiralty and elsewhere, but his greatest contribution has undoubtedly been in the clarification and stabilization of defence research and development policy as a whole over the past few years. His contributions to the rationalization of the research and development programme so as to harmonize the needs of the Services with the national resources have been markedly successful, and a great debt is owed to him for his work in this field. What he has accomplished is due to three qualities which he has in abundance : a real understanding of Service needs and Service modes of thought, a basic understanding of scientific practices and requirements, and a capacity for hard, thorough and clear-headed work equalled by few and probably excelled by none. A distinguished player of games when younger, and an extremely successful scientific agriculturist to-day, it is to be hoped that his advice and his services to the Scientific Civil Service will not wholly end with his departure from the Ministry of Defence.

Sir Solly Zuckerman, C.B., F.R.S.

Sir Solmy Zuckerman, who is to succeed Sir Frederick Brundrett as scientific adviser to the Ministry of Defence, is no stranger to either defence or to Whitehall. Sir Solly was born in South Africa in 1904; he came to Britain in 1925 and rapidly became known as a distinguished research anatomist. $\mathrm{He}$ at present holds the Sands Cox chair of anatomy in the University of Birmingham, and he is especially well known for his work on the primates. During the Second World War his wide scientific talents were drawn on freely by many branches of the Services, but he was perhaps most closely associated with the Royal Air Force, and he made important contributions to the operational analysis of the effects of bombardment, particularly from the air. In the past decade he has combined his work at the University of Birmingham with many other activities, including his duties as honorary secretary of the Zoological Society during a rather stormy period, and with the deputy chairmanship of the Advisory Council on Scientific Policy, towards the work of which and some of its subcommittees, notably the Committee on Scientific Man-Power, he has made a major contribution. $\mathrm{He}$ succeeds Sir Frederick Brundrett at a difficult time when it may well be that a closer integration between civil and defence science is necessary, and when indeed some re-thinking may be necessary on the balance between the two. For this task Sir Solly, by his previous experience, his exceptional ability and warm personality, is excellently qualified.

\section{Meteorological Branch of the Canadian Department of Transport : Dr. Andrew Thomson, O.B.E.}

Dr. Andrew Thomson, who on September 25 retired from the post of director of the Meteorological Branch of the Canadian Department of Transport, a position he has held for the past thirteen years, is well known in the world of meteorology. A graduate of the University of Toronto, his first studies were in geophysics, and during 1920-21 he was put in charge of investigations into atmospheric electricity during the round-the-world cruise of the Carnegie Institution research ship. In 1923 he became director of the Apia Observatory, Samoa, and in 1929 aerologist of the Dominion of New Zealand. He returned to Canada in 1931 as head of the research division of the Meteorological Service, and assumed charge of the whole service in 1946. Dr. Thomson has done much in the international field, especially as a member of the Executive Committee of the World Meteorological Organization and as president of the Regional Association for North and Central America of the World Meteorological Organization. A great traveller, who has not only done much to build up an efficient national service but also to promote international co-operation in meteorology, he was made O.B.E. in 1948, and awarded the gold medal of the Professional Institute of the Public Service of Canada in 1952 and the honorary degree of D.Sc. by McGill University in 1958. He carries into his retirement the best wishes and affection of all who know him.

Mr. Patrick D. McTaggart-Cowan, M.B.E.

The appointment of Mr. P. D. MeTaggart-Cowan to succeed Dr. Andrew Thomson as director of the 